\title{
Fiber composition and degradability of cold season green forage and pre-dried silage harvested at pre-flowering
}

\author{
Composição da fibra e degradabilidade da forragem verde e da \\ silagem pré-secada de cereais de estação fria colhidos em estádio de \\ pré-florescimento
}

\author{
Egon Henrique Horst ${ }^{1 *}$; Mikael Neumann ${ }^{2}$; Jony Cley dos Santos ${ }^{1}$; \\ Juliana Mareze ${ }^{3}$; Ivone Yurika Mizubuti"; Valter Harry Bumbieris Júnior ${ }^{4}$
}

\begin{abstract}
This study aimed to evaluate the contents of hemicellulose, cellulose, and lignin, as well as the rates of dry matter degradability in forage and pre-dried silage of different winter cereals harvested at preflowering. The experiment was conducted by the Animal Production Center (NUPRAN), Department of Agricultural and Environmental Sciences, State University of Midwest (UNICENTRO). It is located in Guarapuava - PR, Brazil. The study was part of the Master's Degree in Crop Production. As experimental materials, we used black oat (Avena strigosa) cv. EMB 139 and cv. IAPAR 61; white oat (Avena sativa) cv. IPR and $126 \mathrm{hp}$. URS Taura; barley (Hordeum vulgare) cv. BRS Brau and cv. BRS Cauê; wheat (Triticum aestivum) cv. BRS Umbu and cv. BRS Tarumã; rye (Secale cereale) cv. Temprano and cv. BRS Serrano; and triticale (X Triticosecale) cv. IPR and $111 \mathrm{hp}$. BRS Saturn. Dry matter degradability was measured by an in situ technique, arranged in a completely randomized block design with three replications (animal), subdivided in subplots. Treatments were the plots and subplots digestion times. The incubation times were $0,6,12,24$, and 48 hours. To that end, we used two 24-month rumen fistulated steers with $350 \mathrm{~kg}$ average weight. A similarity was observed in the results of both forage and pre-dried silage degradability, displaying the same trends. Barley cv. BRS Brau had the highest hemicellulose content in its composition; however, IPR 111 triticale was showed the highest degradability potential, both for green forage and pre-dried silage.
\end{abstract}

Key words: Chemical composition. Ruminal disappearance. Neutral detergent fiber. Hibernal forages. Lignin.

\section{Resumo}

O objetivo do trabalho foi avaliar os teores de hemicelulose, celulose e lignina, bem como a taxa de degradabilidade da matéria seca (MS), da forragem e da silagem pré-secada, de diferentes cereais de estação fria colhidos em estádio de pré-florescimento. O experimento foi conduzido pelo Núcleo de Produção Animal (NUPRAN) junto ao Curso de Mestrado em Agronomia na área de Produção Vegetal, pertencente ao setor de Ciências Agrárias e Ambientais da Universidade Estadual do Centro-Oeste

\footnotetext{
${ }^{1}$ Discentes, Curso de Mestrado, Programa de Pós-Graduação de Agronomia da Universidade Estadual do Centro-Oeste, UNICENTRO, Guarapuava,PR, Brasil.E-mail: egonhh@yahoo.com.br; jony_cley@yahoo.com.br

2 Prof., Programa de Pós-Graduação de Agronomia, UNICENTRO, Guarapuava, PR, Brasil. E-mail: neumann.mikael@hotmail. com

3 Discente, Curso de Mestrado, Programa de Pós-Graduação de Ciência Animal, Universidade Estadual de Londrina, UEL, Londrina, PR, Brasil. E-mail: juliana_mareze@hotmail.com

4 Profs. Drs., Programa de Pós-Graduação de Ciência Animal, Departamento de Zootecnia, UEL, Londrina, PR, Brasil. E-mail: mizubuti54@hotmail.com; dudabumbieris@hotmail.com

* Author for correspondence
} 
(UNICENTRO), localizado no município de Guarapuava - PR. Como material experimental utilizouse aveia preta (Avena strigosa) cv. EMB 139 e $c v$. IAPAR 61; aveia branca (Avena sativa) $c v$. IPR 126 e $c v$. URS Taura; cevada (Hordeum vulgare) $c v$. BRS Brau e $c v$. BRS Cauê; trigo (Triticum aestivum) $c v$. BRS Umbu e $c v$. BRS Tarumã; centeio (Secale cereale) $c v$. Temprano e $c v$. BRS Serrano; e triticale (X Triticosecale) $c v$. IPR 111 e $c v$. BRS Saturno. A degradabilidade da matéria seca foi estimada pela técnica in situ, em um delineamento de blocos inteiramente casualizados, com três repetições (animal), em arranjo de parcelas subdivididas. Os tratamentos constituíram as parcelas e os tempos de digestão as subparcelas. Os tempos de incubação utilizados foram de $0,6,12,24$ e 48 horas. Para tal, foram utilizados dois novilhos com 24 meses de idade, peso vivo (PV) médio de $350 \mathrm{~kg}$, portadores de fístula ruminal. Notou-se uma similaridade entre os resultados de degradabilidade da forragem e da silagem pré-secada, tomando as mesmas tendências. A cevada cv. BRS Brau obteve o maior teor de hemicelulose em sua composição, porém, o triticale IPR 111 foi o tratamento com maior potencial de degradabilidade, tanto como forragem quanto silagem pré-secada.

Palavras-chave: Composição química. Desaparecimento ruminal. Fibra em detergente neutro. Forrageiras hibernais. Lignina.

\section{Introduction}

Numerous models have been developed (ELLIS et al., 1994; FRANCE et al, 1998; MERTENS, 2005), or traditional mathematical functions have been readjusted to the interpreting of results from ruminal kinetic studies. Reliable ruminal degradability estimates are necessary for the application of new prediction equations of ruminant nutritional requirements. Currently, these equations use fixed values of degradability for each type of feed (BUMBIERIS JUNIOR et al., 2011); therefore, further information is still required since there are degradability differences among varieties of the same forage species, for example.

In this context, studies on ruminal degradation kinetics of different ingredients used in ruminant feed, especially bulky fodder, are increasingly gaining attention from researchers. The results obtained so far have proved to be quite promising for also contributing to balancing of diets and meeting ruminant nutritional requirements (PIRES et al., 2006). However, most of these studies are based on tropical forage species due to their great predominance throughout the country.

In a scattered manner, southern Brazil is a privileged region that has a climate able to support yields of cold season crops, which have high nutritional value if compared to most of the tropical species. For instance, Pires et al. (2006) and
Bumbieris Junior et al. (2011) demonstrated high degradability rates for some winter cereals, both highlighting high levels of soluble carbohydrate. Nonetheless, studies on ruminal kinetics of winter cereals are still scarce. On the other hand, it is worth mentioning that these cereals have a high content of crude protein $(\% \mathrm{CP})$ during vegetative phase (FONTANELI et al., 2009), reducing the need for supplementation with protein concentrates and, consequently, having lower diet costs. Furthermore, fiber has more potential for ruminal degradation during this stage.

Finally, there is modification evidence of food nutritional quality during storage since there are enzymes capable of partially hydrolyzing fibrous particles, mainly hemicellulose, increasing feed degradability (ROOKE; HATFIELD, 2003).

Given the above, the aim of this study was to evaluate the contents of hemicellulose, cellulose, and lignin, as well as the dry matter degradability rates of forage and pre-dried silage of different winter cereals harvested at pre-flowering.

\section{Material and Methods}

The experiment was conducted by the Animal Production Center (NUPRAN), Department of Agricultural and Environmental Sciences, State University of Midwest (UNICENTRO). The study 
was part of the Master's Degree in Crop Production. The area is located in Guarapuava city, within a subtropical zone of the Paraná state (Brazil), being at the geographical coordinates of $25^{\circ} 23^{\prime} 02^{\prime \prime}$ south latitude, 51 $21^{\circ}$ ' 43" west longitude, and 1,026-m altitude.

According to Koppen's classification, local climate is a $C f b$ type (mesothermal humid subtropical), with mild summers and mild winters, without dry season or severe frosts. The average annual rainfall is $1,944 \mathrm{~mm}$, annual minimum average temperature of $12.7^{\circ} \mathrm{C}$, annual maximum average temperature of $23.5{ }^{\circ} \mathrm{C}$, and air relative humidity of $77.9 \%$. Figure 1 shows the average rainfall $(\mathrm{mm})$ and insolation (hours day ${ }^{-1}$ ), underlining the averages of maximum and minimum temperature $\left({ }^{\circ} \mathrm{C}\right)$ and air relative humidity $-\mathrm{RH}$ $(\%)$, divided into decades, during the experimental period.

Figure 1. Rainfall $(\mathrm{mm})$, insolation (hours day $\left.{ }^{-1}\right)$, maximum and minimum temperature $\left({ }^{\circ} \mathrm{C}\right)$ and relative humidity $(\%)$ averages of winter cereals throughout growing stage, 2014 crop.
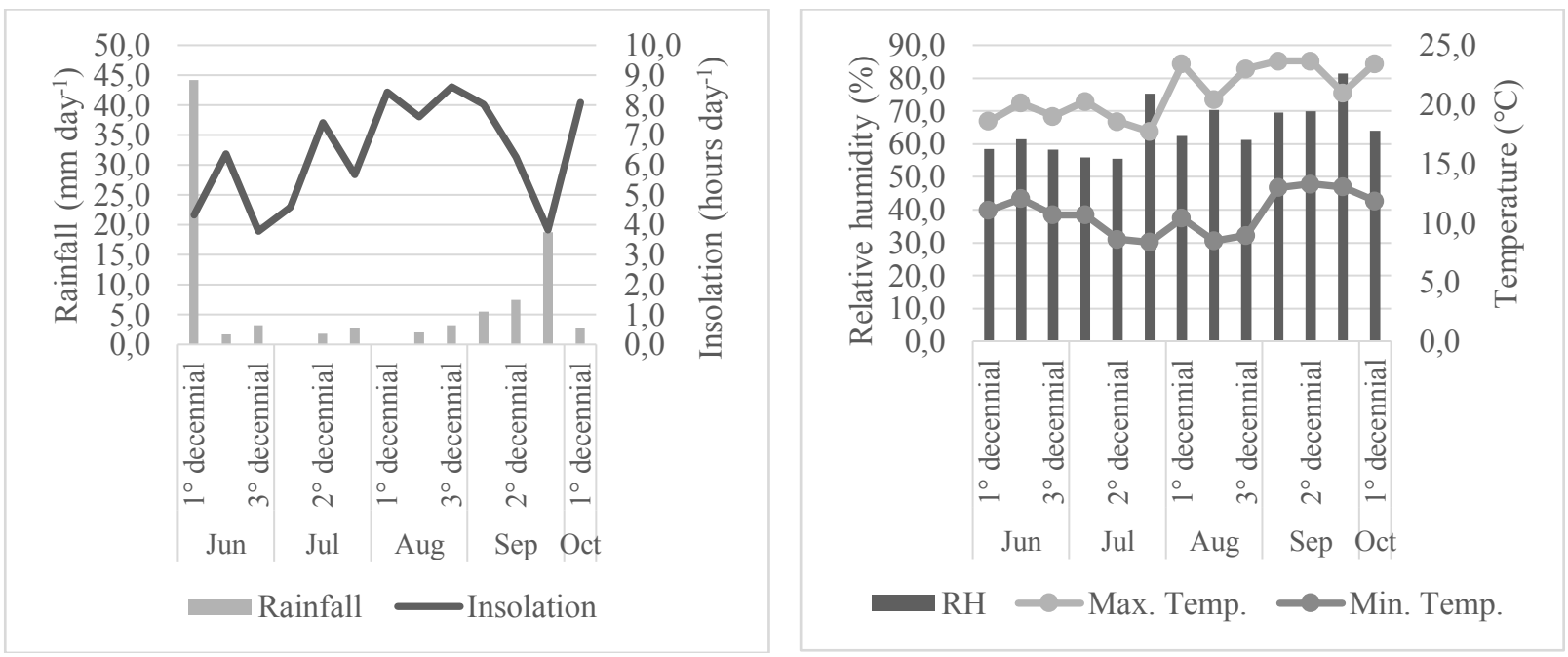

Fonte: SIMEPAR/UNICENTRO experimental station, Guarapuava, PR.

The soil in the experimental was classified as typical bruno Latosol (EMBRAPA, 2006) (i.e. Oxisol). Prior to the sowing of the assessed crop species, soil had the following chemical characteristics (0-20 cm depth layer): $\mathrm{pH}$ in $0.01 \mathrm{M}$ $\mathrm{CaCl}_{2}$ of 4.7 ; P content of $1.1 \mathrm{mg} \mathrm{dm}^{-3} ; \mathrm{K}^{+}$of 0.2 $\mathrm{cmol}_{\mathrm{c}} \mathrm{dm}^{-3}$; OM of $2.62 \mathrm{~g} \mathrm{dm}^{-3} ; \mathrm{Al}^{3+}$ of $0.0 \mathrm{cmol}_{\mathrm{c}}$ $\mathrm{dm}^{-3} ; \mathrm{H}^{+}+\mathrm{Al}^{3+}$ of $5.2 \mathrm{cmol}_{\mathrm{c}} \mathrm{dm}^{-3} ; \mathrm{Ca}^{+}$of $5.0 \mathrm{cmol}_{\mathrm{c}}$ $\mathrm{dm}^{-3} ; \mathrm{Mg}^{2+}$ of $5.0 \mathrm{cmol}_{\mathrm{c}} \mathrm{dm}^{-3}$, and base saturation (V\%) of $67.3 \%$.

The crops were grown in areas according to the agricultural zoning for Guarapuava-PR region, under no-tillage system. Sowing was performed in rows $0.17 \mathrm{~m}$ away from each other, at a $2-\mathrm{cm}$ depth and a sowing density of 300 seeds $\mathrm{m}^{-2}$. The experimental area consisted of $570 \mathrm{~m}^{2}$, in total, being divided into $489-\mathrm{m}^{2}$ plots $(4.00 \mathrm{~m} \times 2.25$ $\mathrm{m})$. Each plot stood for an experimental unit or one replication.

The experimental design was a randomized block composed of twelve treatments and four replications. As experimental materials, we used black oat (Avena strigosa) cv. EMB 139 and cv. IAPAR 61; white oat (Avena sativa) cv. IPR and 126 cv. URS Taura; barley (Hordeum vulgare) cv. BRS Brau and cv. BRS Cauê; wheat (Triticum aestivum) cv. BRS Umbu and cv. BRS Tarumã; Rye (Secale cereale) cv. Temprano and cv. BRS Serrano; and 
triticale ( $X$ Triticosecale) cv. IPR 111 and cv. BRS Saturn.

The collection of material collect occurred when plants reached the pre-flowering stage, near 10 of the Large (1954) scale, being characterized by the end of stem elongation when the flag leaf was fully extended but ears were still unseen.

After harvest, plant material was pre-wilted in the field to reach ideal dry matter (DM) contents for ensilage. In order to accomplish that, laboratory silos, made of PVC tubes $40 \mathrm{~cm}$ high and $10 \mathrm{~cm}$ diameter, were used. The material was pressed manually in silos with a wooden socket. After filling, the silos were sealed with double-sided canvas and tape, being identified, weighed, and stored under shade.

Both during green forage harvest and after opening the silos, $0.5-\mathrm{kg}$ samples of each material were collected and sent immediately to the laboratory of Animal Nutrition for DM content determinations. For that, the samples were placed in forced air-circulation oven at $55{ }^{\circ} \mathrm{C}$ until reaching constant weight. Thereafter, pre-dried samples of original material were ground in a "Willey" type mill with a $1-\mathrm{mm}$ sieve.

These pre-dried samples were used for determinations of neutral detergent fiber (NDF), acid detergent fiber (ADF), and lignin (LIG) following methods proposed by Silva and Queiroz (2009). From the values above-cited, hemicellulose (HEM) contents were calculated by the difference between NDF and ADF, as well as cellulose (CEL) contents by subtracting LIG from ADF.

Dry matter degradability was estimated by an in situ technique using $12 \mathrm{x} 8 \mathrm{-cm}$ nylon bags with 40 - to 60-micrometer mesh, containing nearly $5 \mathrm{~g}$ of each material ground to $1 \mathrm{~mm}$, as described above, for further incubation in the rumen (NOCEK, 1988). Treatments were set in a completely randomized block with three replications, in a split-plot design. Treatments constituted the plots and subplots the digestion times. Incubations lasted for $0,6,12$, $18,24,30,36,42$, and 48 hours, from which the 0 -minute time represented DM soluble fraction outside rumen. Three rumen fistulated 24-month steers, with $350 \mathrm{~kg}$ live weight, were used for incubation.

Data were subjected to the Shapiro-Wilk and Bartlett tests to verify assumptions of normality and variance homogeneity, respectively. Once these assumptions were met, means were compared by the F test at 5\% probability through variance analysis (ANOVA) followed by multiple mean comparison test (Tukey) at 5\% significance using SAS software (1993). DM degradability data underwent regression analysis (proc reg).

\section{Results and Discussion}

Table 1 displays the contents of hemicellulose, cellulose and lignin (in \% of DM), and green forage and pre-dried silage of the different winter cereals harvested at pre-flowering. The analysis of variance showed the statistic difference $(\mathrm{P}<0.05)$ among treatments regardless of the analyzed variable.

Through green forage bromatological analysis, we observed average values of $27.5 \%, 35.3 \%$, and $8.4 \%$ for hemicellulose, cellulose, and lignin, respectively (Table 1). Barley cv. BRS Brau showed the highest amount of hemicellulose and lowest of lignin among all treatments, reaching values of $31.9 \%$ and $5.2 \%$, respectively (Table 1 ). These values were not statistically different $(\mathrm{P}>0,05)$ from wheat cv. EMB Tarumã and triticale BRS Saturn regarding hemicellulose fraction, with values of $30.5 \%$ and $29.9 \%$, respectively; as well as for black oat cv. EMB 139 concerning lignin, with 5.7\% (Table 1).

As noted above, Table 1 also shows that black oat cv. EMB 139 had a low lignin content, with statistically lower hemicellulose content compared to the other forage materials $(\mathrm{P}<0.05)$; however, it had the highest cellulose value in its composition. 
The opposite can be observed for white oat cv. URS Taura, which reached the lowest content of cellulose $(\mathrm{P}<0.05)$ in DM $(28.4 \%)$.

As observed here, the available literature shows a trend in results regarding fiber composition, however, these values are inconstant (MEINERZ et al., 2011a; COAN et al., 2001), proving that pasture management directly influence final quality of the material available for animals (PEREIRA; REIS, 2001).

Table 1. Contents of hemicellulose, cellulose, and lignin (\%) in dry matter of green forage and pre-dried silage of winter cereals harvested at pre-flowering, Guarapuava-PR.

\begin{tabular}{|c|c|c|c|c|c|c|}
\hline \multirow{2}{*}{ Species - Cultivars } & \multicolumn{3}{|c|}{ Green Forage } & \multicolumn{3}{|c|}{ Pre-dried Silage } \\
\hline & HEM & CEL & LIG & HEM & CEL & LIG \\
\hline Black oat - EMB 139 & $23.7 \mathrm{e}$ & $42.3 \mathrm{a}$ & $5.7 \mathrm{de}$ & $27.3 \mathrm{def}$ & $37.5 \mathrm{ab}$ & $9.4 \mathrm{abc}$ \\
\hline Black oat - IAPAR 61 & $25.1 \mathrm{de}$ & $37.1 \mathrm{abc}$ & $9.0 \mathrm{bcd}$ & 26.2 ef & $37.3 \mathrm{ab}$ & $8.6 \mathrm{abc}$ \\
\hline White oat - IPR 126 & $24.8 \mathrm{de}$ & $40.8 \mathrm{ab}$ & 6.4 cde & $26.1 \mathrm{ef}$ & $34.7 \mathrm{ab}$ & $10.2 \mathrm{ab}$ \\
\hline White oat - URS Taura & $27.6 \mathrm{bcd}$ & $28.4 \mathrm{f}$ & $13.6 \mathrm{a}$ & 28.2 cde & $32.6 \mathrm{bc}$ & $6.1 \mathrm{bc}$ \\
\hline Barley- BRS Brau & $31.9 \mathrm{a}$ & 34.4 cde & $5.2 \mathrm{e}$ & $31.4 \mathrm{a}$ & $32.4 \mathrm{bc}$ & $6.8 \mathrm{bc}$ \\
\hline Barley - BRS Cauê & $28.2 \mathrm{bcd}$ & $31.1 \mathrm{de}$ & $6.6 \mathrm{~cd}$ & $29.9 \mathrm{abc}$ & $31.7 \mathrm{bc}$ & $7.1 \mathrm{abc}$ \\
\hline Wheat - BRS Umbu & $29.7 \mathrm{abc}$ & 32.9 def & $9.36 \mathrm{bcd}$ & $28.6 \mathrm{bcd}$ & $34.4 \mathrm{ab}$ & $6.9 \mathrm{bc}$ \\
\hline Wheat - BRS Tarumã & $30.5 \mathrm{ab}$ & $33.1 \mathrm{def}$ & $10.4 \mathrm{ab}$ & $30.2 \mathrm{ab}$ & $33.7 \mathrm{ab}$ & $6.3 \mathrm{bc}$ \\
\hline Rye - Temprano & $27.9 \mathrm{bcd}$ & 36.2 cde & $9.7 \mathrm{bc}$ & $25.7 \mathrm{f}$ & $35.7 \mathrm{ab}$ & $8.3 \mathrm{abc}$ \\
\hline Rye - BRS Serrano & $25.0 \mathrm{de}$ & 36.3 cde & $10.7 \mathrm{ab}$ & $27.4 \mathrm{def}$ & $33.5 \mathrm{ab}$ & $9.4 \mathrm{abc}$ \\
\hline Triticale - IPR 111 & 26.2 cde & $31.8 \mathrm{def}$ & $8.1 \mathrm{~cd}$ & $27.7 \mathrm{def}$ & $26.6 \mathrm{c}$ & $11.5 \mathrm{a}$ \\
\hline Triticale - BRS Saturno & $29.9 \mathrm{ab}$ & $39.5 \mathrm{abc}$ & $6.4 \mathrm{~cd}$ & $29.9 \mathrm{abc}$ & $39.2 \mathrm{a}$ & $5.1 \mathrm{c}$ \\
\hline Average & 27.5 & 35.3 & 8.4 & 28.2 & 34.1 & 8.0 \\
\hline $\mathrm{P}>\mathrm{F}$ & $<0.0001$ & $<0.0001$ & $<0.0001$ & $<0.0001$ & $<0.0001$ & $<0.0001$ \\
\hline $\mathrm{CV} \%$ & 5.21 & 6.11 & 18.01 & 3.42 & 7.16 & 22.94 \\
\hline $\mathrm{R}^{2}$ & 0.8154 & 0.8371 & 0.7924 & 0.8284 & 0.1745 & 0.6270 \\
\hline
\end{tabular}

Averages followed by different letters in the same column differ statistically according to Tukey test at $5 \%$ probability.

Regarding the bromatological values of pre-dried silage, it can be seen, in Table 1, that barley cv. BRS Brau and wheat cv. BRS Tarumã maintained the highest values of hemicellulose fraction $(\mathrm{P}<0.05)$, which were of $31.4 \%$ and $30.2 \%$, respectively, as previously observed for green-forage. However, for pre-dried silage, there was no statistical difference for barley cv. BRS Cauê and triticale BRS Saturn (Table 1). On the other hand, the latter had the lowest lignin content among all treatments, being of 5.1\%, however, showing a significant superiority over the other treatments with respect to the cellulose fraction (39.2\%). For the sum of fiber constituents, shown in Table 1, triticale cv. BRS Saturn generated the highest value of NDF (74.2\%), indicating a lesser consumption capacity than the other silages. It is known that NDF content in any bulky fodder has no direct relationship with consumption, where the greater the amount of hemicellulose, cellulose, and lignin, the lower the animal consumption (VAN SOEST, 1994).

By contrast, triticale cv. IPR 111 was the treatment with the lowest cellulose content $(26.6 \%)$ and the highest of lignin (11.5\%) (Table 1). These values together with hemicellulose fraction resulted in the lowest NDF content (65.8\%), thus, generating the greatest potential for consumption.

Pre-drying provides direct effects on forage carbohydrate content, varying particularly with initial moisture content (PEREIRA; REIS, 2001). When assessing the silage fiber composition of different winter cereals, Meinerz et al. (2011b) found an average value of cellulose fraction similar 
to the one encountered here $(33.8 \%)$; however, they reported higher values of hemicellulose and lower ones of lignin, being of $34.8 \%$ and $4.85 \%$, respectively. It is suggested that such variations are results from losses caused by leaching and volatilization during pre-drying in the field, concentrating the less volatile fractions.

Coan et al. (2001), also evaluating green forage and pre-dried forage, described similar results for fiber composition, and emphasize that pre-drying increases hemicellulose content and decreases both cellulose and lignin, as observed in this study.
Regarding green forage degradability (Figure 2), we noted that barleycv. BRSBrauand IPR 111 triticale were the materials with the highest concentration of soluble carbohydrates, as represented by the curve intercept, with 34.41 and $33.35 \%$, respectively. Conversely, black oat cv. IAPAR $61 \mathrm{hp}$ and the rye cv. Temprano had respectively 20.40 and $22.81 \%$ of soluble carbohydrates in their composition (Figure 2), which might have be related to a high number of stems in these materials.

Figure 2. In situ degradability rates of green forage and pre-dried silage for different winter cereals harvested at preflowering, Guarapuava-PR.

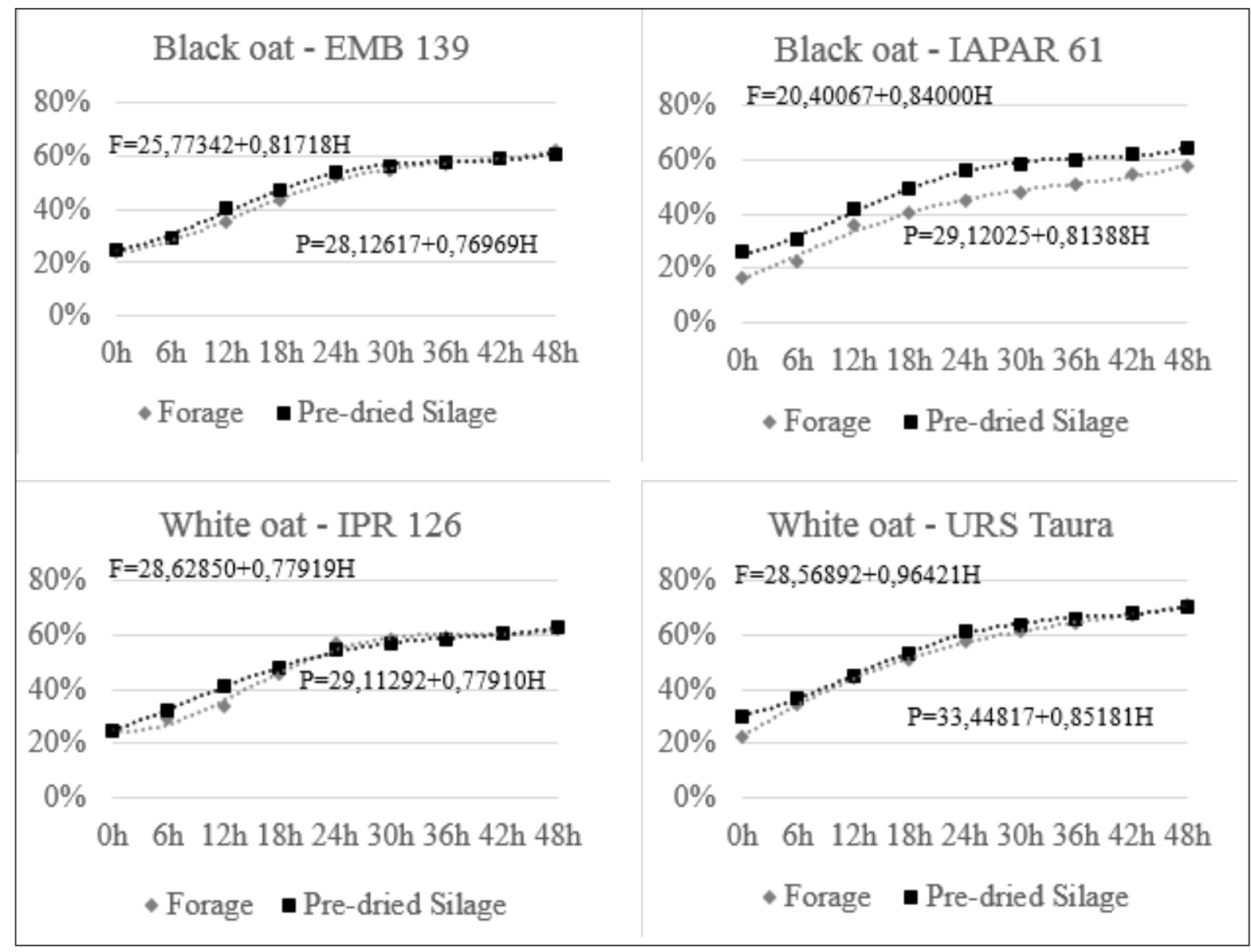




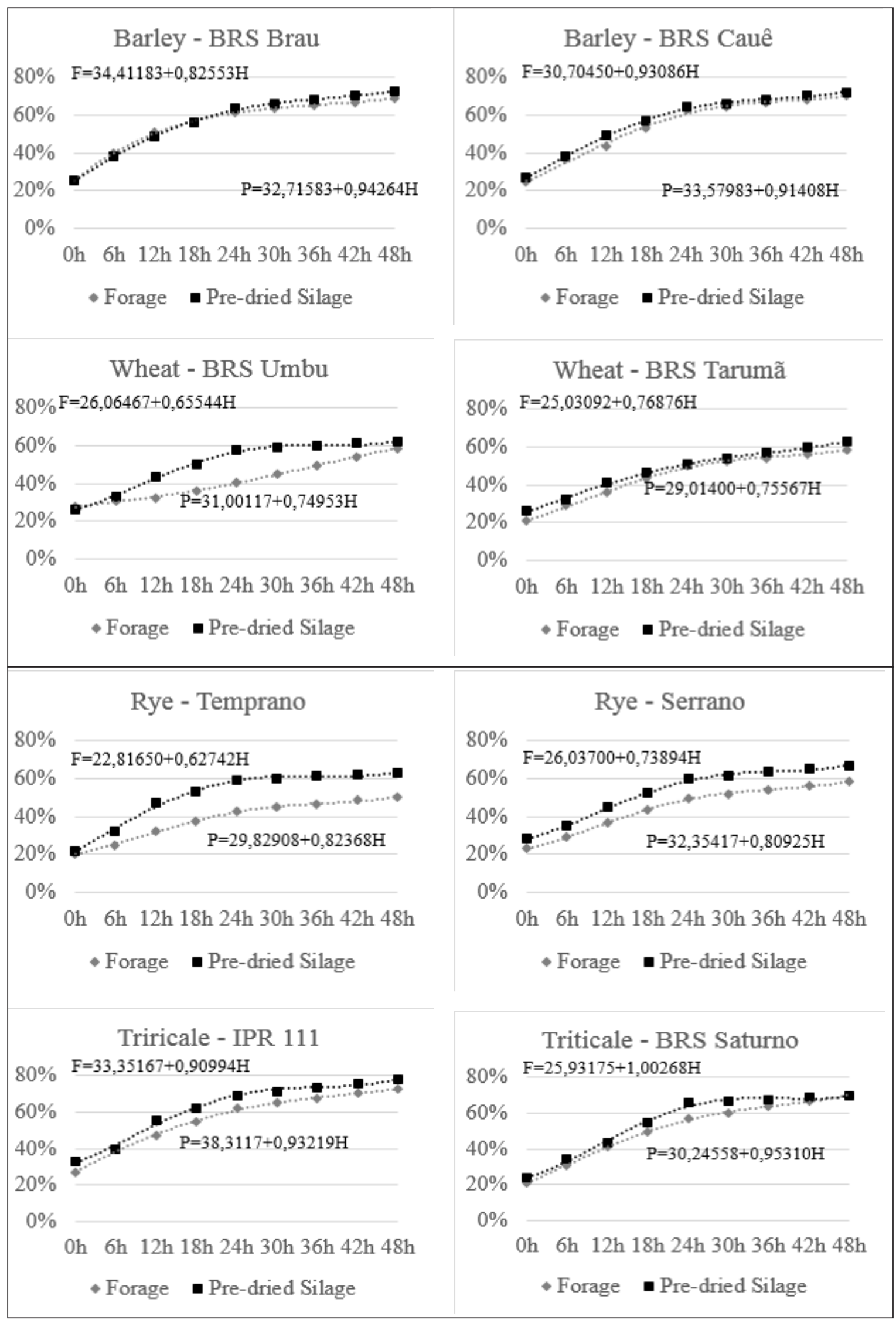


The high content of soluble carbohydrates in green forage of triticale cv. IPR 111 showed higher ruminal degradability after 48 hours, whereas rye cv. Temprano showed the lowest, ranging between 72.7 and $50.29 \%$, respectively. In addition, rye cv. Temprano yielded a degradability rate of $0.62 \%$ hour $^{-1}$, which represents 11.1 percent points less than rye cv. Serrano (Figure 2).

Although Triticale cv. BRS Saturn had $25.93 \%$ soluble carbohydrates in its green forage constitution, it showed high ruminal disappearance rate $\left(1.00 \%\right.$ time $\left.^{-1}\right)$ and, after 48 hours, it increased to $69.95 \%$ degradability. Overall, the values obtained in this study were higher than were those described by Meinerz et al. (2011a).

Still in figure 2, it is possible to see for most of the evaluated materials parallel trend lines for green forage and for pre-dried silage in the course of the time. However, such trend was not noted for BRS Umbu wheat and Temprano rye, which showed similar concentrations of soluble carbohydrates both for forage and for pre-dried silage. Furthermore, we must highlight that throughout the hours pre-dried silage degradability stood out against forage values.

Interestingly, overall treatments, green forage degradability had an average of $63.27 \%$, which is similar to the findings of Roso et al. (2000) but higher than were those described by Moreira et al. (2008). Yet for pre-dried silage, degradability was above $67.10 \%$, corroborating results described by Rooke and Hatfield (2003), who stated that the enzymes in fermentation could partially hydrolyzes fiber particles, especially hemicellulose, increasing feed degradability.

Considering pre-dried silage degradability, we noted that triticale cv. IPR 111 also had the highest content of soluble carbohydrates followed by barley cv. BRS Cauê, showing values of 38.31 and $33.57 \%$, respectively. Notwithstanding, higher hourly rates of degradability were reached by triticale cv. BRS Saturno and barley cv. BRS Brau, which were $0.95 \%$ and 0.94 hours $^{-1}$, respectively (Figure 2).
Also in Figure 2, it is possible to verify that black oat cv. EMB 139 generated the lowest concentration of soluble carbohydrates among all analyzed materials $(28.12 \%)$ but lower ruminal disappearance rate per hour was recorded for wheat cv. BRS Umbu $\left(0.74 \%\right.$ hour $\left.{ }^{-1}\right)$.

After 48 hours exposed to in situ degradability, black oat cv. EMB 139 pre-dried silage had the lowest potential degradation $(60.99 \%)$ while triticale cv. IPR 111 proved to be the most degradable (77.81\%), as seen for green forage. On the general average, the results shown here are similar to those found by Meinerz et al. (2011a), in Santa Maria-RS.

Broadly, DM degradability rates obtained in this study can be classified as good quality since, according to Leng (1990), forages are considered of low quality when present degradability rates lower than $55 \%$.

Finally, it is noteworthy mention that, generally, pre-drying and ensiling have no effect on fiber carbohydrate content as well as dry matter degradability of these materials.

\section{Conclusion}

All the studied materials showed good degradability rates. There was a similarity between degradability of green forage and those of predried silage, with emphasis on barley cv. BRS Brau which reached the highest hemicellulose content and on triticale IPR 111 with the highest potential degradability.

\section{Acknowledgement}

The authors want to thank the CAPES (Coordination for Improvement of Higher Education Personnel) for scholarship grant, enabling the performance of this study. 


\section{References}

BUMBIERIS JUNIOR, V. H.; JOBIM, C. C.; EMILE, J. C.; ROSSI, R.; CALIXTO JUNIOR, M.; BRANCO, A. F. Degradabilidade ruminal e fracionamento de carboidratos e proteínas em silagens de triticale em cultivo singular ou em misturas com aveia e/ou leguminosas. Semina: Ciências Agrárias, Londrina, v. 32, n. 2, p. 759-770, 2011.

COAN, R.; FREITAS, D.; REIS, R.; RODRIGUES, L. Composição bromatológica das silagens de forrageiras de inverno submetidas ou não ao emurchecimento e ao uso de aditivos. ARS Veterinária, Jaboticabal, v. 17, n. 1, p. 58-63, 2001.

EMPRESA BRASILEIRA DE PESQUISA AGROPECUÁRIA - EMBRAPA. Centro Nacional de Pesquisa do Solo. Sistema brasileiro de classificação de solos. 2. ed. Rio de Janeiro, 2006. 306 p.

ELLIS, W. C.; MATIS, J. H.; HILL, T. H.; MURPHY, M. R. Methodology for estimating digestion and passage kinetics of forages. In: FAHERY JUNIOR, G. C. Forage quality, evaluation and utilization. Madison: American Society of Agronomy, 1994. p. 682-756.

FONTANELI, R. S.; FONTANELI, R. S.; SANTOS, H. D.; NASCIMENTO JUNIOR, A.; MINELLA, E.; CAIERÃO, E. Rendimento e valor nutritivo de cereais de inverno de duplo propósito: forragem verde e silagem ou grãos. Revista Brasileira de Zootecnia, Viçosa, MG, v. 38, n. 11, p. 2116-2120, 2009.

FRANCE, J.; DIJKSTRA, J.; DHANOA, M. S.; BALDWIN, R. L. Biomathematical applications in ruminant nutrition. Journal of the Franklin Institute, Philadelphia, v. 335, n. 2, p. 241-258, 1998.

LARGE, E. C. Growth stages in cereals illustration of the Feekes scale. Plant Pathology, Oxford, v. 3, n. 4, p. 128-129, 1954.

LENG, R. A. Factors affecting the utilization of poorquality forages by ruminants particularly under tropical conditions. Nutrition Research Review, Cambridge, v. 3, n. 3, p. 277-303, 1990.

MEINERZ, G. R.; OLIVO, C. J.; FONTANELI, R. S.; AGNOLIN, C. A.; FONTANELI, R. S.; HORST, T.; VIÉGAS, J.; BEM, C. M. Valor nutritivo da forragem de genótipos de cereais de inverno de duplo propósito. Revista Brasileira de Zootecnia, Viçosa, MG, v. 40, n. 6, p. 1173-1180, 2011b.
MEINERZ, G. R.; OLIVO, C. J.; VIÉGAS, J.; NÖRNBERG, J. L.; AGNOLIN, C. A.; SCHEIBLER, R. B.; FONTANELI, R. S. Silagem de cereais de inverno submetidos ao manejo de duplo propósito. Revista Brasileira de Zootecnia, Viçosa, MG, v. 40, n. 10, p. 2097-2104, 2011a.

MERTENS, D. R. Rate and extent of digestion. In: DIJKSTRA, J.; FORBES, J. M.; FRANCE, J. Quantitative aspects of ruminant digestion and metabolism. Connecticut, CAB International Wallingford, 2005. p. 13-47.

MOREIRA, A. L.; RUGGIERI, A. C.; REIS, R. A. Avaliação da aveia-preta e de genótipos de aveia amarela para produção de forragem e de grãos. ARS Veterinária, Jaboticabal, v. 21, p. 175-182, 2008. Suplemento.

NOCEK, J. E. In situ and other methods to estimate ruminal protein and energy digestibility. A review. Journal Dairy Science, Champaign, v. 71, v. 8, p. 2051206, 1988.

PEREIRA, J. R. A.; REIS. R. A. Produção de silagem pré-secada com forrageiras temperadas e tropicais. In: SIMPÓSIO SOBRE PRODUÇÃO E UTILIZAÇÃO DE FORRAGENS CONSERVADAS, 2011, Maringá. Anais... Maringá: Universidade Estadual de Maringá, 2001. p. 64-86.

PIRES, A. J. V.; REIS, R. A.; CARVALHO, G. G. P. D.; SIQUEIRA, G. R.; BERNARDES, T. F.; RUGGIERI, A. C.; ROTH, M. D. T. P. Degradabilidade ruminal da matéria seca, da fração fibrosa e da proteína bruta de forrageiras. Pesquisa Agropecuária Brasileira, Brasília, v. 41, n. 4, p. 643-648, 2006.

ROOKE, J. A.; HATFIELD, R. D. Biochemistry of ensiling. In: BUXTON, D. R.; MUCK, R. E.; HARRISON, J. H. (Ed.). Silage science and technology. Madison: American Society of Agronomy; Crop Science Society of America; Soil Science Society of America, 2003. p. 95-135.

ROSO, C.; RESTLE, J.; SOARES, A. B.; ANDREATTA, E. Aveia preta, triticale e centeio em mistura com azevém. 1 - Dinâmica produção e qualidade de forragem. Revista Brasileira de Zootecnia, Viçosa, MG, v. 29, n. 1, p. 7584, 2000.

SILVA, D. J.; QUEIROZ, A. C. Análise de alimentos: métodos químicos e biológicos. 3. reimp. Viçosa, Universidade Federal de Viçosa, 2009. 235 p.

SAS INSTITUTE. SAS Language reference. Version 6, Cary, NC, 1993. 1042 p.

VAN SOEST, P. J. Nutritional ecology of the ruminant. $2^{\text {th }}$ ed. Corvallis: O \& B Books, 1994. 415 p. 
